\title{
Promotion of Axon Regeneration by Myelin-Associated Glycoprotein and Nogo through Divergent Signals Downstream of $\mathrm{G}_{\mathrm{i}} / \mathrm{G}$
}

\author{
Yuiko Hasegawa, ${ }^{1,2 \star}$ Masashi Fujitani, ${ }^{1 \star}$ Katsuhiko Hata, ${ }^{1}$ Masaya Tohyama, ${ }^{2}$ Satoru Yamagishi, ${ }^{1}$ and \\ Toshihide Yamashita ${ }^{1}$ \\ ${ }^{1}$ Department of Neurobiology, Graduate School of Medicine, Chiba University, Chiba 260-8670, Japan, and 2Department of Anatomy and Neuroscience, \\ Graduate School of Medicine, Osaka University, Osaka 565-0871, Japan
}

\begin{abstract}
Several myelin-derived proteins have been identified as components of the CNS myelin that prevents axonal regeneration in the adult vertebrate CNS. Activation of RhoA has been shown to be an essential part of the signaling mechanism of these proteins. Here we report an additional signal, which determines whether these proteins promote or inhibit axon outgrowth. Myelin-associated glycoprotein (MAG) and Nogo trigger the intracellular elevation of $\mathrm{Ca}^{2+}$ as well as the activation of PKC, presumably mediated by $\mathrm{G}_{\mathrm{i}} / \mathrm{G}_{\text {. Neurite }}$ outgrowth inhibition and growth cone collapse by MAG or Nogo can be converted to neurite extension and growth cone spreading by inhibiting conventional PKC, but not by inhibiting inositol 1,4,5-triphosphate $\left(\mathrm{IP}_{3}\right)$. Conversely, neurite growth of immature neurons promoted by MAG is abolished by inhibiting $\mathrm{IP}_{3}$. Activation of RhoA is independent of PKC. Thus, a balance between $\mathrm{PKC}_{\text {and }} \mathrm{IP}_{3}$ is important for bidirectional regulation of axon regeneration by the myelin-derived proteins.
\end{abstract}

Key words: p75; myelin; myelin-derived proteins; G-protein; PKC; spinal

\section{Introduction}

Three distinct myelin proteins, myelin-associated glycoprotein (MAG), Nogo, and oligodendrocyte myelin glycoprotein, inhibit axon growth by binding to a common receptor, the Nogo receptor (McKerracher and Winton, 2002). Because the Nogo receptor is glycoslyphosphatidylinositol-linked to the cell surface and does not have an intracellular signaling domain, it plays a role as a binding partner for the myelin proteins. Recently, p75 ${ }^{\text {NTR }}$ in complex with the Nogo receptor has been shown to be a signaltransducing element for these proteins (Wang et al., 2002; Wong et al., 2002; Yamashita et al., 2002). One potential clue to understanding the signal transduction mechanism involved is found through observations demonstrating that the small GTPase Rho is a key intracellular effector for growth inhibitory signaling by myelin. In its active GTP-bound form, Rho rigidifies the actin cytoskeleton, thereby inhibiting axon elongation and mediating growth cone collapse (Davies, 2000; Schmidt and Hall, 2002). RhoA, a member of the Rho GTPases family, is activated by MAG, Nogo, and oligodendrocyte myelin glycoprotein through a p75 ${ }^{\text {NTR }}$-dependent mechanism, thus inhibiting neurite outgrowth from postnatal sensory neurons and cerebellar neurons

Received April 6, 2004; revised June 10, 2004; accepted June 11, 2004.

This work was supported in part by The General Insurance Association of Japan, by Grant-in-Aid 14657343 from the Ministry of Education, Culture, Sports and Technology of Japan, and by the Research Grant (15A-2) for Nervous and Mental Disorders from the Ministry of Health, Labor, and Welfare.

${ }^{*}$ Y.H. and M.F. contributed equally to this work.

Correspondence should be addressed to Toshihide Yamashita, Department of Neurobiology, Graduate School of Medicine, Chiba University, 1-8-1 Inohana, Chuo-ku, Chiba 260-8670, Japan. E-mail: t-yamashita@faculty.chiba-u.jp. D0I:10.1523/JNEUROSCI.1856-04.2004

Copyright $\odot 2004$ Society for Neuroscience $\quad 0270-6474 / 04 / 246826-07 \$ 15.00 / 0$
(Wang et al., 2002; Yamashita et al., 2002). Regulation of RhoA activity by MAG and Nogo through $\mathrm{p} 75^{\text {NTR }}$ is mediated by the release of RhoA from Rho GDP dissociation inhibitor (GDI), which suppresses the activity of RhoA (Yamashita and Tohyama, 2003).

Although RhoA seems to play a key role in regulating axon growth, we were interested in the possibility that some other signals also may influence the effects of the myelin-derived inhibitors. An intriguing observation is that MAG promotes axon growth from dorsal root ganglion (DRG) neurons of rats up to postnatal day 4 (P4) (Johnson et al., 1989; Mukhopadhyay et al., 1994). This finding lead to the possibility that the myelin-derived proteins are bifunctional molecules inhibiting or promoting axon regeneration. To test this hypothesis, we examined other signals that may be regulated by these proteins.

Here we report a new signal, which determines whether these proteins promote or inhibit axon outgrowth or growth cone spreading. MAG and Nogo trigger the intracellular elevation of $\mathrm{Ca}^{2+}$ as well as the activation of PKC. Neurite outgrowth inhibition and growth cone collapse by MAG or Nogo can be converted to neurite extension and growth cone spreading by inhibiting conventional PKC. Conversely, neurite growth of immature neurons promoted by MAG is abolished by inhibiting inositol 1,4,5triphosphate $\left(\mathrm{IP}_{3}\right)$. A balance between $\mathrm{PKC}$ and $\mathrm{IP}_{3}$ is suggested to be a key factor for bidirectional regulation of axon regeneration by the myelin-derived proteins.

\section{Materials and Methods}

Calcium imaging. Cultured cells were coloaded with the cell permeant 4 mM Fura Red AM and 4 mm Oregon Green 488 BAPTA-1 (Molecular 
Probes, Eugene, OR) for $1 \mathrm{hr}$ at $37^{\circ} \mathrm{C}$ and imaged with the Leica confocal imaging system. Hank's MEM was used to prevent $\mathrm{pH}$ changes during experiments. The antibody against the extracellular domain of $\mathrm{p} 75^{\mathrm{NTR}}$ was added $2 \mathrm{hr}$ before imaging, and U73122 (50 nM), U73343 (50 nM), or pertussis toxin (PTX) $(20 \mathrm{ng} / \mathrm{ml})$ was added $30 \mathrm{~min}$ before imaging. The cells were illuminated with $488 \mathrm{~nm}$ light from an argon laser. Fluorescence images for the entire cell body were used for ratiometric calcium measurements. Fura Red and Oregon Green emission signals were collected at $605-700$ and $500-560 \mathrm{~nm}$, respectively, and analyzed at $10 \mathrm{sec}$ intervals. The Oregon Green/Fura Red ratio was calculated by dividing pixel values at $530 \mathrm{~nm}$ by those at $640 \mathrm{~nm}$. MAG-Fc chimera (R \& D Systems, Minneapolis, MN) or human Siglec-3-Fc chimera (R \& D Systems) was used at the concentration of $25 \mu \mathrm{g} / \mathrm{ml}$. The number of the cells examined is $70-120$ for each experimental group (five to seven independent experiments were done for each).

Assessment of PKC activities. PKC assays were performed using the PepTag assay kit for nonradioactive detection of protein kinase $\mathrm{C}$ system (Promega, Madison, WI). Serum-starved cultured cerebellar cells were stimulated by MAG-Fc $(25 \mu \mathrm{g} / \mathrm{ml})$ and the Nogo peptide ( $4 \mu \mathrm{M}$; Alpha Diagnostic, San Antonio, TX) in the presence or absence of PTX (20 $\mathrm{ng} / \mathrm{ml}$ ). The inhibitors at the indicated concentration have been shown previously to be effective in enhancing the Rho activity as well as neurite inhibition (Tang et al., 1997b; Yamashita et al., 2002; Yamashita and Tohyama, 2003). Each sample was incubated with the PKC substrate PepTag $\mathrm{C} 1$ peptide $(2 \mu \mathrm{g})$ at $30^{\circ} \mathrm{C}$ for $30 \mathrm{~min}$. The samples were separated on a $0.8 \%$ agarose gel at $100 \mathrm{~V}$ for $15 \mathrm{~min}$. Phosphorylated peptide substrate migrated toward the anode $(+)$, whereas nonphosphorylated peptide substrate migrated toward the cathode $(-)$. The gel was photographed on a transilluminator.

For assessment of phosphorylated PKC, phosphospecific antibodies were used. The cells were lysed with $0.1 \%$ NP-40 containing $10 \mathrm{~mm}$ Tris- $\mathrm{HCl}, \mathrm{pH} 7.5,150 \mathrm{~mm} \mathrm{NaCl}, 10 \%$ glycerol, $100 \mathrm{~mm}$ sodium orthovanadate, $50 \mathrm{~mm}$ sodium fluoride, $5 \mathrm{~mm}$ sodium pyrophosphate, 1 mM EGTA, and protease inhibitor mixture (Roche Biochemicals). The lysates were subjected to SDS-PAGE, followed by immunoblot analysis. Polyclonal anti-phospho PKC- $\alpha$ (Ser 657; Upstate Biotechnology, Charlottesville, VA), phospho-PKC- $\zeta / \lambda$ (Cell Signaling Technology, Beverly, MA), and PKC $\alpha$ (Santa Cruz Biotechnology, Santa Cruz, CA) antibodies were used. In other sets of experiments, the lysates were incubated with anti-PKC- $\alpha$, -PKC- $\beta 1$, or -PKC- $\beta 2$ (all from Santa Cruz Biotechnology), followed by incubation with protein G-Sepharose (Amersham Biosciences, Arlington Heights, IL) for $2 \mathrm{hr}$ at $4^{\circ} \mathrm{C}$. The beads were washed three times and subjected to SDS-PAGE, followed by immunoblot analysis. Western blotting was done using the antibody against phosphorylated pan-PKC (Cell Signaling Technology). Specificity of antibodies against PKC- $\beta 1$ or PKC- $\beta 2$ has been described in multiple references (Miranti et al., 1999). Anti-PKC- $\alpha$ antibody reacts with PKC- $\alpha$ and very weakly with PKC- $\beta 1$ and $-\beta 2$. Anti-PKC- $\beta 1$ and $-\mathrm{PKC}-\beta 2$ are specific to corresponding isoform.

Neurite outgrowth assay. Dorsal root ganglia were removed from P1 rats and dissociated into single cells by incubation with $0.025 \%$ trypsin (Sigma, St. Louis, MO) for $15 \mathrm{~min}$ at $37^{\circ} \mathrm{C}$. For cerebellar neurons, the cerebella from two animals (both P7 rats) were combined in $5 \mathrm{ml}$ of $0.025 \%$ trypsin, triturated, and incubated for $10 \mathrm{~min}$ at $37^{\circ} \mathrm{C}$. DMEM containing 10\% FCS was added, and the cells were centrifuged at 800 $\mathrm{rpm}$. Neurons were plated in Sato media (Doherty et al., 1990) on polyL-lysine-coated chamber slides. For outgrowth assays, plated cells were incubated for $24 \mathrm{hr}$, fixed in $4 \%$ (weight per volume) paraformaldehyde, and immunostained with a monoclonal antibody $(\mathrm{TuJ} 1)$ for the purpose of recognizing the neuron-specific $\beta$-tubulin III protein. The length of the longest neurite or the total process outgrowth for each $\beta$-tubulin III-positive neuron was then determined. For each experiment, we measured at least 100 neurites length and repeated the same experiments three times. Where indicated, MAG-Fc $(25 \mu \mathrm{g} / \mathrm{ml})$, the Nogo peptide (4 $\mu \mathrm{M})$, PTX (2 ng/ml; Sigma), U73122 (20 nM; Sigma), Xestspongin C (XestC) (1 $\mu \mathrm{M}$; Sigma), the cell-permeable PKC inhibitor 20-28 (2 $\mu \mathrm{M}$; Calbiochem, La Jolla, CA), G 6976 (200 nM; Sigma), or myristoylated PKC $\theta$ pseudosubstrate ( $2 \mu \mathrm{M}$; Sigma) was added to the medium after plating.
Growth cone collapse assay. Explants of embryonic day 12 (E12) chick dorsal root ganglion were incubated for $24 \mathrm{hr}$ on plastic slides precoated with $100 \mu \mathrm{g} / \mathrm{ml}$ poly-L-lysine and treated for $30 \mathrm{~min}$ with soluble CNS myelin extracts (Sigma) at the indicated concentrations, MAG-Fc (25 $\mu \mathrm{g} / \mathrm{ml}$ ) or the Nogo peptide ( $4 \mu \mathrm{M}$ ). Explants were fixed in $4 \%(\mathrm{w} / \mathrm{v})$ paraformaldehyde and stained with fluorescence-labeled phalloidin (Sigma). For each experiment, we assessed at least 100 growth cones, and we repeated the same experiments three times.

Affinity precipitation of GTP-RhoA. Cells were lysed in $50 \mathrm{~mm}$ Tris, $\mathrm{pH}$ 7.5 , containing $1 \%$ Triton $\mathrm{X}-100,0.5 \%$ sodium deoxycholate, $0.1 \%$ SDS, $500 \mathrm{~mm} \mathrm{NaCl}$, and $10 \mathrm{mM} \mathrm{MgCl}_{2}$, with leupeptin and aprotinin, each at $10 \mu \mathrm{g} / \mathrm{ml}$ (Ren et al., 1999). Cell lysates were clarified by centrifugation at $13,000 \times g$ at $4^{\circ} \mathrm{C}$ for $10 \mathrm{~min}$, and the supernatants were incubated with $20 \mu \mathrm{g}$ of GST-Rho binding domain of Rhotekin beads (Upstate Biotechnology) at $4^{\circ} \mathrm{C}$ for $45 \mathrm{~min}$. The beads were washed four times with a washing buffer (50 mM Tris, pH 7.5, containing 1\% Triton X-100, 150 $\mathrm{mm} \mathrm{NaCl}, 10 \mathrm{~mm} \mathrm{MgCl}_{2}$, and $10 \mu \mathrm{g} / \mathrm{ml}$ each of leupeptin and aprotinin). Bound Rho proteins were detected by Western blotting using a monoclonal antibody against RhoA (Santa Cruz Biotechnology).

\section{Results}

\section{Phospholipase C-PKC/IP 3 pathways are activated by MAG and Nogo}

It has been shown previously that MAG induces a rise in intracellular $\mathrm{Ca}^{2+}$ concentration in cultured Xenopus spinal neurons (Wong et al., 2002) and that MAG-dependent repulsion of axonal growth cones requires $\mathrm{Ca}^{2+}$ signaling (Song et al., 1998). We confirmed these findings through a series of experiments using cerebellar neurons from P7 rats. Fluorescence imaging using the $\mathrm{Ca}^{2+}$-sensitive dyes Oregon Green 488 BAPTA-1 and Fura Red showed that the cytosolic $\mathrm{Ca}^{2+}$ was significantly elevated in the soma of the cells within $1 \mathrm{~min}$ after the addition of MAG-Fc to the medium (Fig. $1 a-c$ ). We were unable to monitor $\mathrm{Ca}^{2+}$ signals on the neurites because of the limited amount of fluorescent dyes loaded into these small cerebellar cell neurites (Xiang et al., 2002). The rapid and massive $\mathrm{Ca}^{2+}$ elevation we observed in the cerebellar neurons is different from the previous observation using Xenopus spinal neurons, for which the $\mathrm{Ca}^{2+}$ increase was mild (Wong et al., 2002). This may be attributable to the fact that our imaging was performed in the cell bodies, whereas Wong et al. (2002) observed the growth cones. No increase in the intracellular $\mathrm{Ca}^{2+}$ was observed by human Siglec-3-Fc, one of the members of the Ig superfamily (Fig. 1c). Results showed that the $\mathrm{Ca}^{2+}$ elevation was blocked by U73122, an inhibitor of phospholipase C (PLC), but not by U73343 (Fig. 1c). Because PLC is a major downstream effector of $\mathrm{G}_{\mathrm{i}}$, a heterotrimeric GTP-binding protein, in neurons, intracellular $\mathrm{Ca}^{2+}$ elevation may be dependent on the activation of $G_{i}-P L C$. Involvement of the $G_{i}$ pathway is suggested by the observation that MAG blocks neurotrophininduced cAMP accumulation (Cai et al., 1999), which is attenuated by PTX, an inhibitor of the $\mathrm{G}_{\mathrm{i}}$ and $\mathrm{G}_{0}$ proteins. These results suggest that the G-proteins activated by MAG inhibit accumulation of cAMP. Indeed, the increase in the $\mathrm{Ca}^{2+}$ concentration by MAG-Fc was attenuated by PTX as well (Fig. 1c). As reported previously (Wong et al., 2002), elevation of $\mathrm{Ca}^{2+}$ by MAG-Fc was inhibited by the antibody against the extracellular domain of p75 ${ }^{\text {NTR }}$ (data not shown), thereby demonstrating that $\mathrm{p} 75^{\text {NTR }}$ participates in the $\mathrm{Ca}^{2+}$ signal. These findings not only confirm the previous results but also suggest that $G_{i}-P L C$ is activated by MAG.

Activation of PLC leads to the hydrolysis of phosphatidylinositol 4,5-bisphosphate $\left(\mathrm{PIP}_{2}\right)$ and produces two cytoplasmic second messengers (Berridge, 1998): diacylglycerol (DAG) and $\mathrm{IP}_{3}$. PKC activation results from the production of DAG together with the elevation of $\mathrm{Ca}^{2+}$ because of $\mathrm{IP}_{3}$-sensitive $\mathrm{Ca}^{2+}$ release 
a)
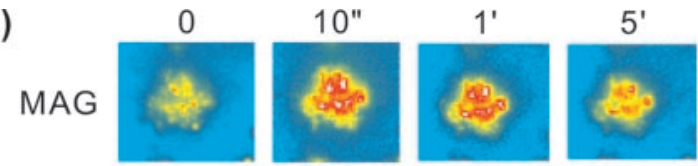

b)

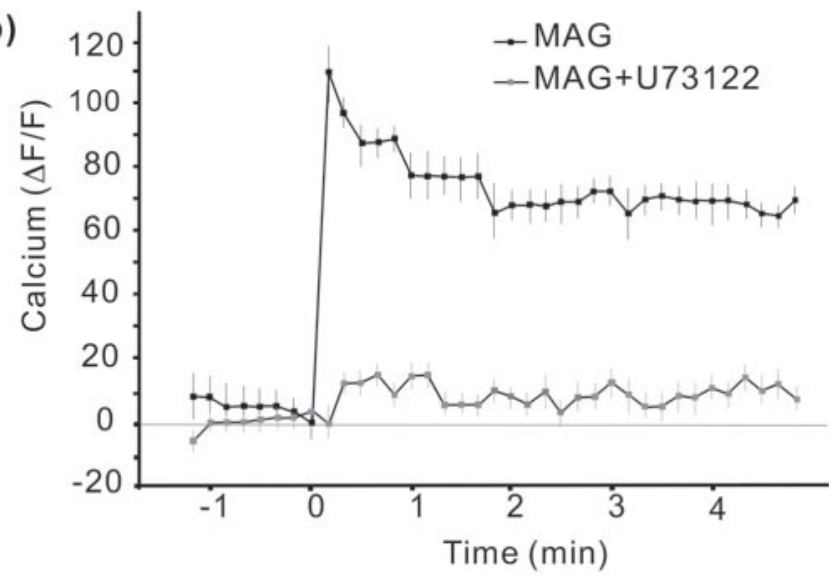

c)

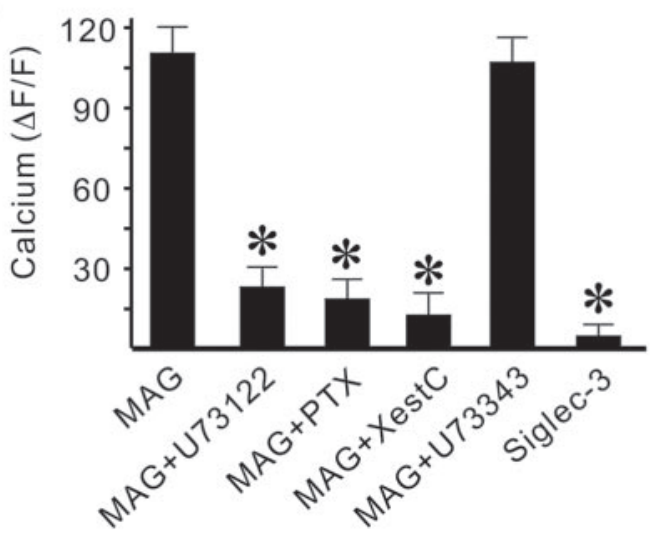

Figure 1. $\mathrm{PLC}-\mathrm{IP}_{3}$ pathways are activated by $M A G$ and Nogo. $a$, Fluorescence images of the cell bodies of a cultured cerebellar neuron, which was loaded with the $\mathrm{Ca}^{2+}$-sensitive fluorescence indicators Fura Red and Oregon Green 488 BAPTA-1.b, $\mathrm{Ca}^{2+}$ signaling triggered by MAG is dependent on $\mathrm{G}_{\mathrm{i}}-\mathrm{PLC}$ activation. The percentage change in the fluorescence ratio $\left(F_{530} / F_{640}\right)$ at 530 and $640 \mathrm{~nm}$ at the soma of the cerebellar neurons before and after application of $M A G-F c$ (25 $\mu \mathrm{g} / \mathrm{ml})$ in normal medium and in medium supplemented with U73122 (50 nM) is shown. Data are mean \pm SE. C, Summary of the percentage change ( $\pm S E$ ) in the fluorescence ratio $\left(F_{530} / F_{640}\right) 0-4$ min after MAG application with or without U73122, PTX $(20 \mathrm{ng} / \mathrm{ml})$, or XestC pretreatment. Data are mean $\pm \mathrm{SE}(n=5)$. Asterisks indicate statistical significance. ${ }^{*} p<$ 0.01 (Student's $t$ test).

from internal stores. These results prompted us to examine whether PKC is involved in MAG or Nogo signaling in cerebellar neurons. When cultured cells were treated for 5 min with 25 $\mu \mathrm{g} / \mathrm{ml}$ MAG or a $4 \mu \mathrm{M}$ concentration of the Nogo peptide, the PKC activity was significantly increased (Fig. 2a). Activation of PKC by MAG-Fc or the Nogo peptide was prevented by $20 \mathrm{ng} / \mathrm{ml}$ PTX. These results suggest the activation of the MAG- or Nogomediated $G_{i}$ pathways, which in turn trigger PKC activation as well as $\mathrm{IP}_{3}$ receptor activation. Our results are consistent with data published very recently (Sivasankaran et al., 2004) showing the activation of PKC by anti-phospho-PAN-PKC antibody. PKC- $\alpha,-\beta 1,-\beta 2$, and $-\gamma$ are expressed as conventional PKC in postnatal cerebellar neurons (data not shown). Western blot analysis revealed a significant increase in phosphorylation of PKC- $\alpha$ at Ser 657 by MAG-Fc, whereas protein levels of PKC- $\alpha$ were not significantly changed (Fig. 2b). However, experiments using phosphospecific antibodies showed that some of atypical a)

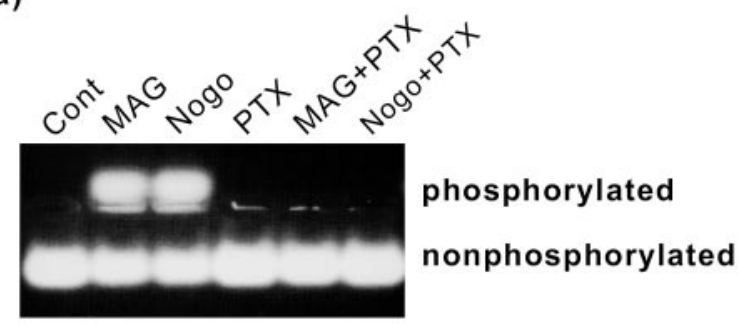

b)

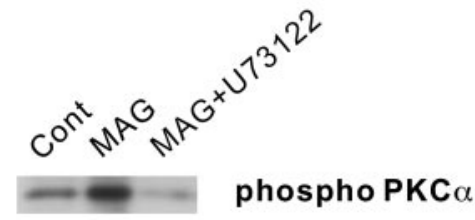

$m$ total PKC $\alpha$

c)

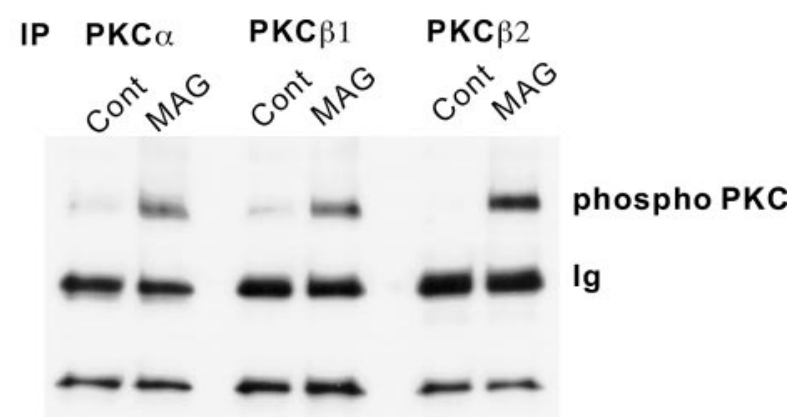

Figure 2. Conventional PKCs are activated by MAG and Nogo. $a$, Representative $(n=4)$ image that shows activation of PKC by MAG and Nogo in cultured cerebellar neurons. Note that the activation of PKC (phosphorylated) is abolished by pretreatment with PTX. MAG, MAG-Fc (25 $\mu \mathrm{g} / \mathrm{ml})$; Nogo, the Nogo peptide $(4 \mu \mathrm{M}) . b$, Representative image $(n=3)$ that shows phosphorylation of PKC $-\alpha$ by MAG-Fc in cultured cerebellar neurons. The bottom panel shows total PKC $-\alpha$. c, Representative image $(n=3)$ that shows phosphorylation of PKC- $\alpha,-\beta 1$, or - $\beta 2$ by MAG-Fc in cultured cerebellar neurons. Each isoform of conventional PKCs is immunoprecipitated (IP) with specific antibody and blotted with anti-phosphorylated pan-PKC antibody. Cont, Control.

PKCs, PKC- $\zeta / \lambda$, were not phosphorylated by MAG (data not shown). To explore further isoform specific activation of conventional PKC, we immunoprecipitated each isoform of conventional PKC with the specific antibodies and immunoblotted with panphospho PKC antibody. Results showed that PKC- $\alpha,-\beta 1$, and $-\beta 2$ were activated by MAG-Fc (Fig. $2 c)$. These results demonstrate that conventional PKCs are activated by MAG-Fc.

\section{Promotion of neurite outgrowth by MAG and Nogo when} PKC is inhibited

We next examined whether the $G_{i}$ pathway is associated with the effects of MAG or Nogo on the neurite outgrowth. It was shown that soluble MAG, released in abundance from myelin and found in vivo, and MAG-Fc could inhibit axon growth (Tang et al., 1997a,b). MAG-Fc at $25 \mu \mathrm{g} / \mathrm{ml}$ inhibited neurite outgrowth of cerebellar neurons from P7 rats (Fig. $3 a$ ). Fc had no effect on the neurons (data not shown). The exact same results were obtained regardless of whether total process outgrowth or length of the longest neurite was measured (data not shown). The Nogo peptide $(4 \mu \mathrm{M})$ also significantly inhibited the neurite outgrowth (Fig. 3a). However, neither PTX nor U73122 modulated the action of MAG-Fc or the Nogo peptide (Fig. 3a). These results 
a)

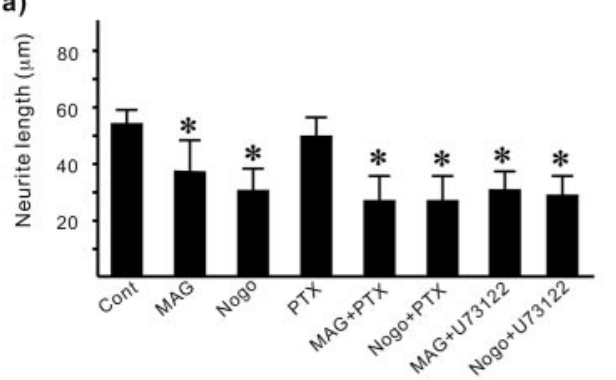

b)

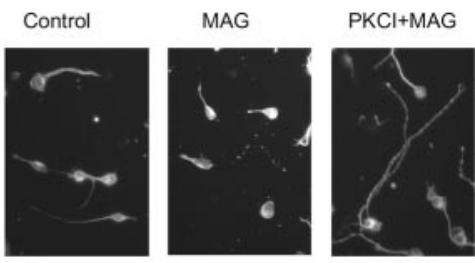

c)

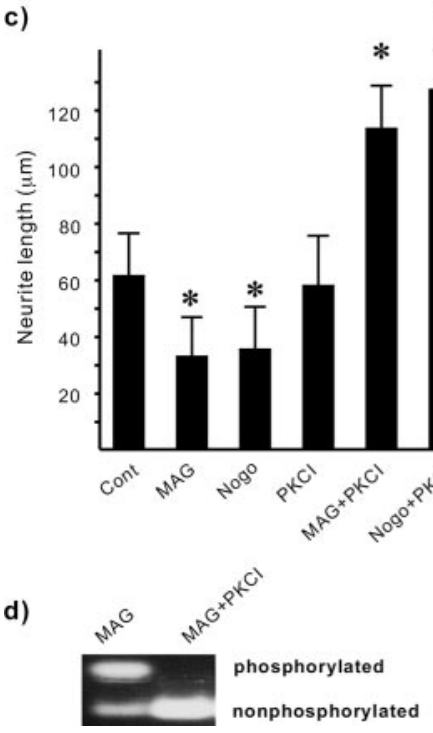

$*$

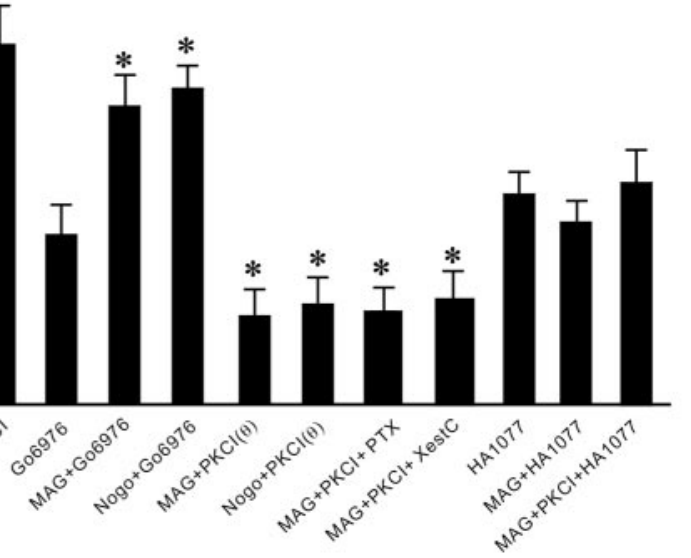

Figure 3. MAG and Nogo stimulate neurite outgrowth when PKC is inhibited. $a$, Neurite outgrowth of cerebellar neurons. MAG, MAG-Fc ( $25 \mu \mathrm{g} / \mathrm{ml})$; Nogo, the Nogo peptide (4 $\mu \mathrm{M})$; PTX, PTX (2 ng/ml); U73122, U73122 (20 nм). Data are mean \pm SE. b, Dissociated cerebellar neurons were incubated for $24 \mathrm{hr}$ with or without MAG-Fc and the PKC inhibitor peptide. Neurons were then immunostained with monoclonal antibody (TuJ1) for the purpose of recognizing the neuron-specific $\beta$-tubulin III protein. MAG, MAG-Fc $(25 \mu \mathrm{g} / \mathrm{ml})$; PKCl, the PKC inhibitor $(2 \mu \mathrm{M})$. c, Neurite outgrowth of cerebellar neurons. MAG-Fc as well as the Nogo peptide stimulates neurite outgrowth in the presence of the PKC inhibitor. MAG, MAG-Fc ( $25 \mu \mathrm{g} / \mathrm{ml})$; Nogo, the Nogo peptide (4 $\mu \mathrm{M})$; PKCl, the PKC inhibitor (2 $\mu \mathrm{m})$; HA1077, a Rho-kinase inhibitor (10 mM); PKCI $(\theta)$, myristoylated PKC $\theta$ pseudosubstrate (2 $\mu \mathrm{M}$ ). Data are mean \pm SE. Asterisks indicate statistical significance. ${ }^{*} p<0.01$ (Student's $t$ test). $d$, Representative figure showing that activation of PKC (phosphorylated) by MAG-Fc is abolished by pretreatment with the PKC inhibitor ( $2 \mu \mathrm{M})$ Cont, Control.

outgrowth in the presence of soluble MAG-Fc, Sivasankaran et al. (2004) demonstrated that $\mathrm{G}_{0} 6976$ abolished the neurite inhibitory effect of the MAG-Fc substrate. Different observations of the effects of $\mathrm{G}_{0} 6976$, which should be elucidated in the future, might be attributable to the culture conditions: soluble MAG-Fc in our assay and MAG as a substrate in their assay. These data show bidirectional regulation of neurite elongation by MAG and Nogo, which is dependent on the activity of conventional PKC.

\section{Growth cone spreading by myelin-derived inhibitors}

To confirm the neurite growth assay data, we adopted another assay to test the function of MAG or Nogo-66. Chick E12 DRG neurons are known to respond to MAG or Nogo-66 (Fournier et al., 2001). We used chick E12 DRG explants to monitor the effects of MAG-Fc and the Nogo peptide on neuronal growth cones. Bath applications of MAG-Fc $(25 \mu \mathrm{g} / \mathrm{ml})$ or the Nogo peptide $\left(\begin{array}{ll}4 & \mu \mathrm{M}\end{array}\right)$ exhibited significant growth cone-collapsing activity (Fig. $4 a, b)$. Consistent with the data obtained by the neurite outgrowth assays, MAG-Fc and the Nogo peptide enhanced the spreading of growth cones in the presence of the PKC inhibitor compared with the control. Although purified myelin from bovine white matter elicited growth cone collapse at $0.1-10 \mathrm{ng} / \mu \mathrm{l}$, the PKC inhibitor completely reversed the effects mediated by myelin (Fig. 4b). These findings suggest that MAG, Nogo, and myelin inhibit neurite outgrowth and elicit growth cone collapse by activating PKC, whereas promotion of neurite outgrowth and spreading of suggest that neither $G_{i}$ nor PLC is associated with the inhibitory effects of MAG or Nogo in regard to regulation of neurite elongation.

There are two divergent signaling cascades downstream of PLC activation: the $\mathrm{PKC}$ and $\mathrm{IP}_{3}$ pathways. Therefore, we tested the hypothesis that a balance of the two signals may have an effect on these inhibitors. The involvement of PKC in the function of MAG and Nogo was assessed first. Surprisingly, MAG-Fc and the Nogo peptide dramatically stimulated neurite outgrowth in the presence of a specific membrane-permeable inhibitor of PKC- $\alpha$ and $-\beta$, although the PKC inhibitor itself had no effect on the growth (Fig. $3 b, c$ ). PKC activity was blocked by the inhibitor (Fig. $3 d)$. The extent of neurite outgrowth induced by MAG-Fc or the Nogo peptide was found to be approximately twice as much as that in the control condition. Myristoylated PKC $\theta$ pseudosubstrate did not modulate the effect of MAG-Fc or the Nogo peptide (Fig. 3c). The neurite length induced by MAG-Fc and the PKC inhibitor returned to that with MAG-Fc alone, when pertussis toxin or XestC was added together with the PKC inhibitor (Fig. $3 c$ ). The same results as the PKC inhibitor were obtained when $\mathrm{G}_{0} 6976$, another inhibitor of PKC- $\alpha$,- $\beta$, and $-v$, was used (Fig. $3 c$ ). Although our data show that $\mathrm{G}_{0} 6976$ promoted neurite growth cones by these inhibitors are mediated by a mechanism that is independent of PKC. Considering that the inhibition of $\mathrm{G}_{\mathrm{i}}$ or PLC did not result in the modulation of the effects mediated by MAG or Nogo, a balancing mechanism of two pathways, diverging at a point downstream of heterotrimeric $G_{i}$ and PLC, may determine whether these inhibitors promote or inhibit neurite outgrowth as well as growth cone spreading.

\section{Dependence on PLC-PKC/IP 3 pathways}

Because our data demonstrate that conventional $\mathrm{PKC}$ is involved in the effects of myelin-derived inhibitors, we next focused on $\mathrm{IP}_{3}$, another signal downstream of $\mathrm{G}_{\mathrm{i}}$ and PLC. To test whether the $\mathrm{IP}_{3}$ pathway mediates the effect of MAG and Nogo, we bathapplied XestC, an inhibitor of the $\mathrm{IP}_{3}$ receptor. The increase in the $\mathrm{Ca}^{2+}$ concentration by MAG-Fc was attenuated by XestC (Fig. 1c). In contrast to the PKC inhibitor, neurite outgrowth inhibition by MAG-Fc or the Nogo peptide in cerebellar neurons was enhanced further by XestC (Fig. $5 a$ ). In these neurons, therefore, the $\mathrm{PKC}$ pathway may dominate over the $\mathrm{IP}_{3}$ pathway, leading to inhibition of neurite outgrowth in response to MAG and Nogo.

A possible mechanism of the conversion from inhibition to 
a)

Control
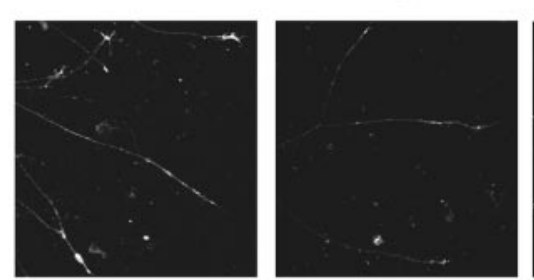

b)

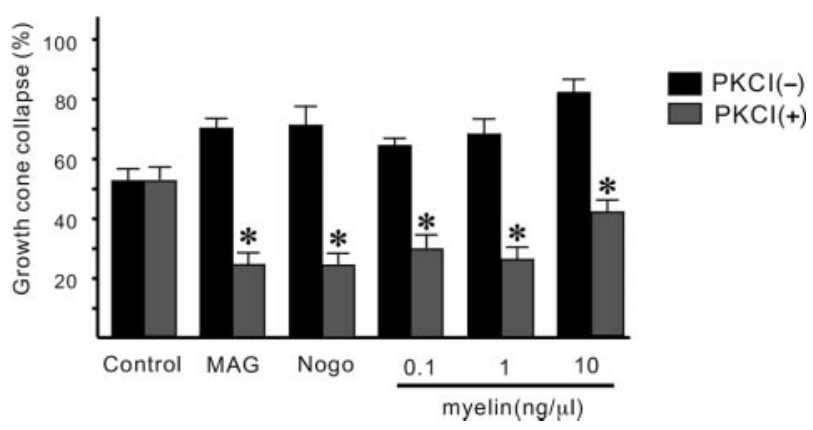

Figure 4. PKC regulates myelin-elicited growth cone collapse. $a$, Growth cone collapse assays. E12 chick DRG explants were treated with MAG-Fc $(25 \mu \mathrm{g} / \mathrm{ml})$ in the presence or absence of the PKC inhibitor (PKCl; $2 \mu \mathrm{m}$ ). Note the prominent spreading of growth cones induced by MAG-Fc in the explant pretreated with the PKC inhibitor. $b$, Results of growth cone collapse assays. We used $0.1-10 \mathrm{ng} / \mu \mathrm{l}$ CNS myelin for the treatment. MAG, MAG-Fc $(25 \mu \mathrm{g} / \mathrm{ml})$; Nogo, the Nogo peptide (4 $\mu \mathrm{m}) ; \mathrm{PKCl}$, the PKC inhibitor peptide $(2 \mu \mathrm{m})$. Data are mean $\pm \mathrm{SE}$. Asterisks indicate statistical significance. ${ }^{*} p<0.01$ (Student's $t$ test).

a)

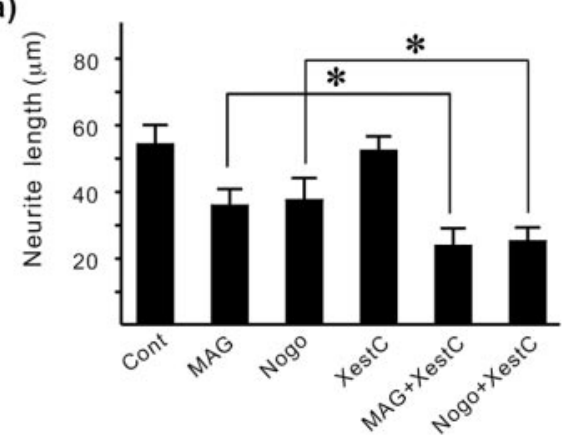

b)

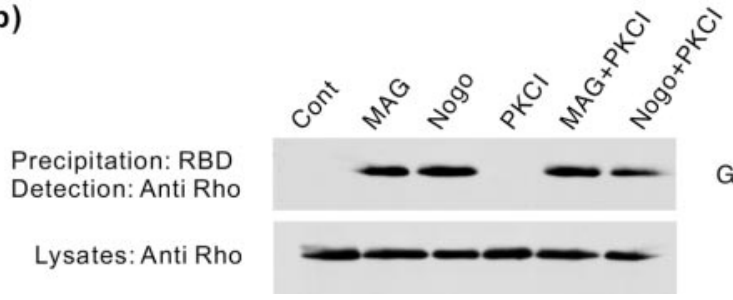

Figure 5. PKC is independent of Rho activation. $a$, Neurite outgrowth of cerebellar neurons. MAG, MAG-Fc $(25 \mu \mathrm{g} / \mathrm{ml})$; Nogo, the Nogo peptide $(4 \mu \mathrm{m})$; XestC, XestC (1 $\mu \mathrm{m})$. XestC enhanced the effect of MAG-Fc or the Nogo peptide. Data are mean \pm SE. Asterisks indicate statistical significance. ${ }^{*} p<$ 0.01 (Student's $t$ test). b, Affinity precipitation of RhoA in cerebellar neurons. RBD, Rho binding domain. MAG-Fc and the Nogo peptide activate RhoA in the presence or absence of the PKC inhibitor. MAG, MAG-Fc (25 $\mu \mathrm{g} / \mathrm{ml})$; Nogo, the Nogo peptide (4 $\mu \mathrm{m})$; PKCl, the PKC inhibitor peptide (2 $\mu \mathrm{m})$. These results were reproducible $(n=3)$. Cont, Control.

promotion of the axon regeneration induced by MAG or Nogo is that PKC modulates Rho activity, because Rho has been shown to be a key signaling molecule in inhibiting neurite elongation (Wang et al., 2002; Yamashita et al., 2002). To address this, we a)

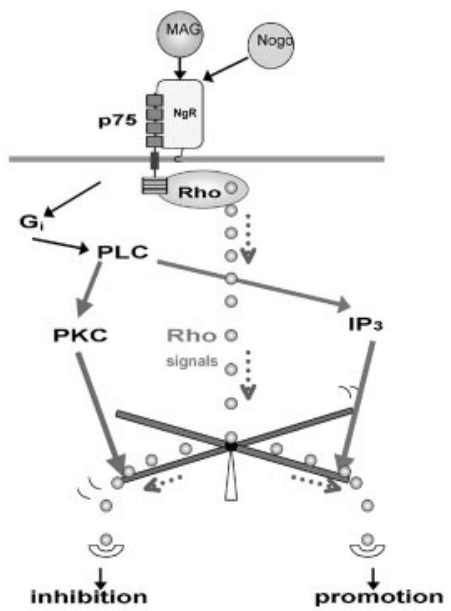

b)

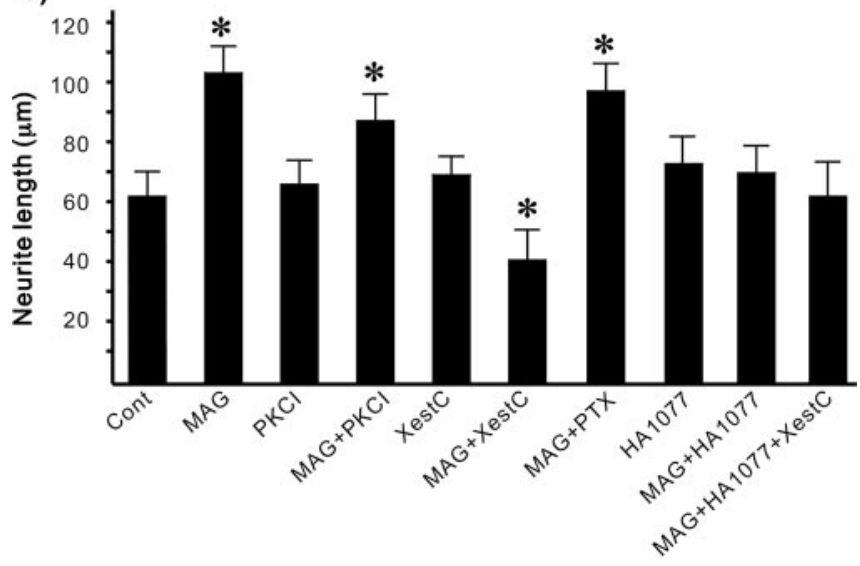

Figure 6. Balancing mechanism is important for the regulation of neurite outgrowth. $a$, MAG and Nogo activate RhoA as well as the $G_{i}-P L C$ pathway. When PKC dominates, MAG and Nogo inhibit neurite outgrowth as well as growth cone spreading, as opposed to when $\mathbb{P}_{3}$ dominates. $b$, Promotion of neurite outgrowth of P1 DRG neurons by MAG is dependent on $\mathbb{P}_{3}$ but not on PKC. Neurite outgrowth of DRG neurons from P1 rats is shown. MAG, MAG-Fc (25 $\mu \mathrm{g} / \mathrm{ml})$; PKCl, the PKC inhibitor peptide (2 $\mu \mathrm{m})$; XestC, XestC (1 $\mu \mathrm{m})$; HA1077 (10 mm), a Rho-kinase inhibitor. Data are mean \pm SE. Asterisks indicate statistical significance. ${ }^{*} p<0.01$ (Student's t test). Cont, Control.

measured RhoA activity in the neurons. Using the RhoA-binding domain of the effector protein Rhotekin (Ren et al., 1999), the GTP-bound form of RhoA can be affinity-precipitated. The assay revealed that RhoA was activated $30 \mathrm{~min}$ after the addition of MAG-Fc or the Nogo peptide to the P7 rat cerebellar neurons (Fig. 5b). The PKC inhibitor had no effect on the Rho activity induced by MAG-Fc or the Nogo peptide. Thus, the promotion of neurite outgrowth of the cerebellar neurons by the inhibiting influence of PKC was not mediated by blocking RhoA activation, showing that conventional PKC is not upstream of RhoA.

MAG promotes axon growth from DRG neurons of rats up to postnatal day 4 (Johnson et al., 1989; Mukhopadhyay et al., 1994), suggesting that responses to these inhibitory cues are dependent on cell type and cell context and not simply on age. Because inhibition of PKC leads to the promotion of axon outgrowth by MAG in postnatal cerebellar neurons, it is postulated that the $\mathrm{IP}_{3}$ pathway dominates over the PKC pathway when $\mathrm{G}_{\mathrm{i}}$-PLC is activated in these DRG neurons (Fig. 6a). To assess this, the neurite outgrowth from dissociated DRG neurons from P1 rats was measured. As before, MAG-Fc $(25 \mu \mathrm{M})$ promoted neurite outgrowth from the DRG neurons (Fig. 6b). Results showed 
that MAG-Fc significantly inhibited neurite outgrowth if treated with XestC, whereas the PKC inhibitor or PTX had no modulating effect on the growth. These findings clearly show that MAG promotes neurite outgrowth, depending on the activity of $\mathrm{IP}_{3}$.

Finally, to assess whether activation of RhoA is necessary for these effects mediated by MAG-Fc or Nogo, a Rho-kinase inhibitor, HA1077, was used at $10 \mathrm{mM}$. HA1077, which efficiently blocked the effects of MAG-Fc on the neurite outgrowth from cerebellar neurons, abolished also the effects of MAG-Fc plus the PKC inhibitor (Fig. 3c). In DRG neurons from $\mathrm{P} 1$ rats, the neurite-promoting effect of MAG-Fc was abolished by HA1077, although HA1077 itself had no effect (Fig. 6b). In addition, HA1077 abolished the effect of XestC in these neurons.

\section{Discussion}

A new signal was identified with regard to the important effects mediated by MAG, Nogo, and myelin. These inhibitors efficiently promoted neurite outgrowth and elicited growth cone spreading of the neurons when conventional PKC was inhibited, compared with the controls. Our data are consistent with those of Sivasankaran et al. (2004) and extend them. Promotion of neurite outgrowth of the immature neurons by MAG was converted to inhibition if $\mathrm{IP}_{3}$ was inhibited. Because inhibition of $\mathrm{G}_{\mathrm{i}}$ or PLC did not result in the modulation of the effects mediated by MAG or Nogo, it is suggested that a balance of the divergent signals is the determinant of these effects. Because PTX did not modulate the effects mediated by MAG on both types of neurons, basal activities of PKC and $\mathrm{IP}_{3}$ may be important for the regulation of neurite outgrowth in the presence of PTX. Future study will focus on the molecular mechanism of how these divergent signals are regulated.

Because the elevation of intracellular $\mathrm{Ca}^{2+}$ concentration induced by MAG is abolished when treated with the antibody against p $75^{\mathrm{NTR}}, \mathrm{p} 75^{\mathrm{NTR}}$ may be required for the signal transduction. Therefore, some G-protein-coupled receptors may be functionally associated with $\mathrm{p} 75^{\mathrm{NTR}}$ to transduce the conventional $\mathrm{PKC} / \mathrm{IP}_{3}$ signals. It has long been known that $\mathrm{p} 75^{\mathrm{NTR}}$ is a receptor for neurotrophins that promote survival and differentiation. Consistent with its function in controlling the survival and neurite formation of neurons, $\mathrm{p} 75^{\mathrm{NTR}}$ is expressed during the developmental stages of the nervous system. In contrast, $\mathrm{p} 75^{\mathrm{NTR}}$ is re-expressed in various pathological conditions in the adult and may even act as an inhibitor of axon regeneration. Our data provide conceptual evidence that the myelin-derived proteins are bifunctional regulators of axon growth. Diverse effects mediated by $\mathrm{p} 75^{\mathrm{NTR}}$ are, in part, the consequence of the interaction of p75 ${ }^{\text {NTR }}$ with other membrane-associated proteins, such as Trk tyrosine kinases, the Nogo receptor and the ganglioside GT1b, and multiple intracellular signaling molecules (Dechant and Barde, 2002). The precise molecular mechanism of $G_{i}-P L C$ signals related to $\mathrm{p} 75^{\mathrm{NTR}}$ should be explored, perhaps by searching for interactors with $\mathrm{p} 75^{\mathrm{NTR}}$.

Previous studies suggest that Rho plays a central role in integrating myelin-derived growth inhibitory signals. Rho is activated by myelin, MAG, and NogoA (McKerracher and Winton, 2002). We note that Rho signal is a prerequisite for the regulation of neurite elongation, because inhibition of Rho results in disappearance of the effects (Yamashita et al., 2002). Rho activity was not affected by modulating the activity of conventional PKC. Activation of RhoA by soluble MAG was slow (5-10 min after exposure) (Niederost et al., 2002; Yamashita et al., 2002), whereas the elevation of the intracellular $\mathrm{Ca}^{2+}$ concentration by MAG-Fc is very rapid. Therefore, it is suggested that there is some cross talk between PKC and the downstream signals of Rho, eliciting bidirectional effects on actin cytoskeleton reorganization.

There are some reports exploring the role of $\mathrm{Ca}^{2+}$ with regard to neurite outgrowth. Takei et al. (1998) demonstrated that $\mathrm{IP}_{3}$ receptor in the neurons has an important role in neurite extension and that local loss of $\mathrm{IP}_{3}$ receptor function results in growth arrest and neurite retraction, although the neurons undergo $\mathrm{Ca}^{2+}$ influx across the plasma membrane. Considering these results and our data indicating that XestC inhibits the neurite extension induced by $\mathrm{MAG}-\mathrm{Fc}, \mathrm{IP}_{3}$ receptor function, but not $\mathrm{Ca}^{2+}$ itself, might be important for the regulation of neurite elongation. The precise molecular events should be explored in the future.

It is known that inactivation of Rho or one of its intracellular targets, Rho kinase, actually abolishes the effects of myelin, MAG, and NogoA, thereby providing potential therapeutic agents against CNS injuries (McKerracher and Winton, 2002). Another promising agent is the silencing peptide that associates with the intracellular domain of $\mathrm{p} 75^{\mathrm{NTR}}$ (Yamashita and Tohyama, 2003). p $75^{\mathrm{NTR}}$, which transduces the signal from every myelin-derived inhibitor found to date, facilitates the release of Rho GDI from RhoA, thus enabling RhoA to be activated by guanine nucleotide exchange factors. Therefore, the peptide inhibits the association of Rho GDI with $\mathrm{p} 75^{\mathrm{NTR}}$ and the signal transduction. In addition, the peptide antagonist of the Nogo receptor and the IN-1 antibody that was generated against a fraction of myelin are shown to be effective in CNS axon regeneration (McKerracher and Winton, 2002). Previous work implicates the cAMP-PKA pathway in the neurite outgrowth regulation (Cai et al., 1999, 2001; Neumann et al., 2002; Qiu et al., 2002), showing that previous activation of this pathway counteracts the effects of the inhibitors in vitro as well as in vivo. A consequence of activation of cAMP-PKA was shown to be the synthesis of polyamines, resulting from an upregulation of Arginase I, a key enzyme in their synthesis (Cai et al., 2002). Inhibition of polyamine synthesis blocked the cAMP effect on regeneration. Many of the proposed strategies either block inhibitory proteins or block signaling by inhibitory proteins. In contrast, our data demonstrate that PKC has the effect of reversing the function of these inhibitors and instead promoting neurite outgrowth or growth cone spreading, providing a potent molecular target against CNS injuries. Myelin-derived inhibitors may act as trophic factors for axotomized neurons under certain conditions. However, it should be noted that none of the neurons used in this study are relevant ones for spinal cord injury. This is a general problem, because much work investigating the in vitro function of the axon growth inhibitors does not use relevant neurons because of the technical difficulty. Because different neurons have different responses to the inhibitors, it is important to focus on the relevant target population to permit identification of relevant pathways in future studies.

\section{References}

Berridge MJ (1998) Neuronal calcium signaling. Neuron 21:13-26.

Cai D, Shen Y, De Bellard M, Tang S, Filbin MT (1999) Prior exposure to neurotrophins blocks inhibition of axonal regeneration by MAG and myelin via a cAMP-dependent mechanism. Neuron 22:89-101.

Cai D, Qiu J, Cao Z, McAtee M, Bregman BS, Filbin MT (2001) Neuronal cAMP controls the developmental loss in ability of axons to regenerate. J Neurosci 21:4731-4739.

Cai D, Deng K, Mellado W, Lee J, Ratan RR, Filbin MT (2002) Arginase I and polyamines act downstream from cyclic AMP in overcoming inhibition of axonal growth MAG and myelin in vitro. Neuron 35:711-719.

Davies AM (2000) Neurotrophins: neurotrophic modulation of neurite growth. Curr Biol 10:R198-R200.

Dechant G, Barde YA (2002) The neurotrophin receptor p75(NTR): novel 
functions and implications for diseases of the nervous system. Nat Neurosci 5:1131-1136.

Doherty P, Fruns M, Seaton P, Dickson G, Barton CH, Sears TA, Walsh FS (1990) A threshold effect of the major isoforms of NCAM on neurite outgrowth. Nature 343:464-466.

Fournier AE, GrandPre T, Strittmatter SM (2001) Identification of a receptor mediating Nogo-66 inhibition of axonal regeneration. Nature 409:341-346.

Johnson PW, Abramow-Newerly W, Seilheimer B, Sadoul R, Tropak MB, Arquint M, Dunn RJ, Schachner M, Roder JC (1989) Recombinant myelin associated glycoprotein confers neural adhesion and neurite outgrowth function. Neuron 3:377-385.

McKerracher L, Winton MJ (2002) Nogo on the go. Neuron 36:345-348.

Miranti CK, Ohno S, Brugge JS (1999) Protein kinase C regulates integrininduced activation of the extracellular regulated kinase pathway upstream of Shc. J Biol Chem 274:10571-10581.

Mukhopadhyay G, Doherty P, Walsh FS, Crocker PR, Filbin MT (1994) A novel role for myelin-associated glycoprotein as an inhibitor of axonal regeneration. Neuron 13:757-767.

Neumann S, Bradke F, Tessier-Lavigne M, Basbaum AI (2002) Regeneration of sensory axons within the injured spinal cord induced by intraganglionic cAMP elevation. Neuron 34:885-893.

Niederost B, Oertle T, Fritsche J, McKinney RA, Bandtlow CE (2002) Nogo-A and myelin-associated glycoprotein mediate neurite growth inhibition by antagonistic regulation of RhoA and Racl. J Neurosci 22:10368-10376.

Qiu J, Cai D, Dai H, McAtee M, Hoffman PN, Bregman BS, Filbin MT (2002) Spinal axon regeneration induced by elevation of cyclic AMP. Neuron 34:895-903.

Ren XD, Kiosses WB, Schwartz MA (1999) Regulation of the small GTPbinding protein Rho by cell adhesion and the cytoskeleton. EMBO J 18:578-585.
Schmidt A, Hall A (2002) Guanine nucleotide exchange factors for Rho GTPases: turning on the switch. Genes Dev 16:1587-1609.

Sivasankaran R, Pei J, Wang KC, Zhang YP, Shields CB, Xu XM, He Z (2004) PKC mediates inhibitory effects of myelin and chondroitin sulfate proteoglycans on axonal regeneration. Nat Neurosci 7:261-268.

Song H, Ming G, He Z, Lehmann M, McKerracher L, Tessier-Lavigne M, Poo MM (1998) Conversion of neuronal growth cone responses from repulsion to attraction by cyclic nucleotides. Science 281:1515-1518.

Takei K, Shin RM, Inoue T, Kato K, Mikoshiba K (1998) Regulation of nerve growth mediated by inositol 1,4,5-triphosphate receptors in growth cones. Science 282:1705-1708.

Tang S, Shen YJ, DeBellard ME, Mukhopadhyay G, Salzer JL, Crocker PR, Filbin MT (1997a) Myelin-associated glycoprotein interacts with neurons via a sialic acid binding site at ARG118 and a distinct neurite inhibition site. J Cell Biol 138:1355-1366.

Tang S, Woodhall RW, Shen YJ, deBellard MD, Saffell JL, Doherty P, Walsh FS, Filbin MT (1997b) Soluble myelin-associated glycoprotein found in vivo inhibits axonal regeneration. Mol Cell Neurosci 9:333-346.

Wang KC, Kim JA, Sivasankaran R, Segal R, He Z (2002) p75 interacts with the Nogo receptor as a co-receptor for Nogo, MAG and OMgp. Nature 420: $74-78$

Wong ST, Henley JR, Kanning KC, Huang KH, Bothwell M, Poo MM (2002) p75(NTR) and Nogo receptor complex mediates repulsive signaling by myelin-associated glycoprotein. Nat Neurosci 5:1302-1308.

Xiang Y, Li y, Zhang Z, Cui K, Wang S, Yuan XB, Wu CP, Poo MM, Duan S (2002) Nerve growth cone guidance mediated by G protein-coupled receptors. Nat Neurosci 5:843-848.

Yamashita T, Tohyama M (2003) The p75 receptor acts as a displacement factor that releases Rho from Rho-GDI. Nat Neurosci 6:461-467.

Yamashita T, Higuchi H, Tohyama M (2002) The p75 receptor transduces the signal from myelin-associated glycoprotein to Rho. J Cell Biol 157:565-570. 